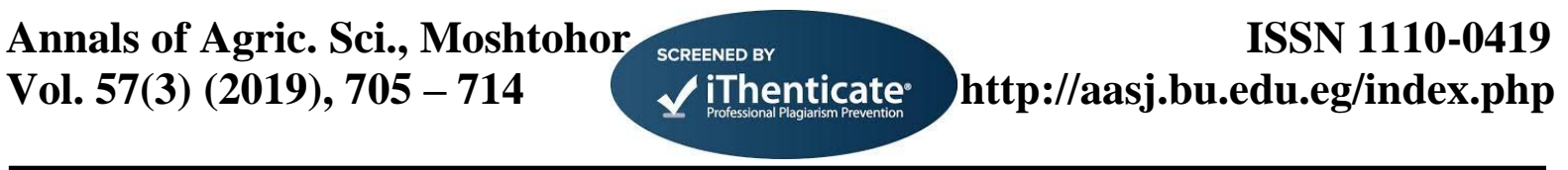

\title{
Effect of Adding Pomegranate Peels and Seeds Powder on Quality Properties of Pan Bread
}

\author{
Rafik M. Abolila ${ }^{1,2}$, Hamam E. M. Bahlol ${ }^{1}$, Ayman S. Dyab ${ }^{3}$, Galal A. Ghazal ${ }^{1}$ \\ and Mahmoud H.M. Mahmoud ${ }^{1}$ \\ ${ }^{1}$ Food Technology Dept., Fac. Agric., Benha Univ., Egypt, ${ }^{2}$ Hero Nutrition Food Industries. Tersa, Kalyoubia., \\ Egypt, ${ }^{3}$ Horticulture Crops TechnologyResearch Department, (FTRI), Agricultural Research Center, Giza, \\ Egypt. \\ Corresponding author: rafikmahmoud_vitrac@hotmail.com
}

\begin{abstract}
The aim of this studytoevaluate the effect of fortified with different levels of pomegranate peel powder (PPP) and pomegranate seed powder (PSP) which having high nutritional value, as partially substitute for wheat flour on quality attributes ofpan bread. The results showed that the pan breadtreatments containing ( $2 \%$ peels $+4 \%$ seeds) $\mathrm{T} 1,(3 \%$ peels $+6 \%$ seeds) $\mathrm{T} 2,(4.5 \%$ peels $+9 \%$ seeds) $\mathrm{T} 3$ and $(6 \%$ peels $+12 \%$ seeds) $\mathrm{T} 4$ had the highest protein, ether extract, fiber and ash content ondry weight compared by control sample (100\% wheat flour) while available carbohydrate was decreased in pan bread treatments (T1:T4) compared to control sample. On the other hand, the addition of PPP and PSP at different levels to pan bread, waseffective in enhancing antioxidant activity, as evaluated by DPPH, which increased to $2.69 \pm 0.20,3.29 \pm 0.13,4.31 \pm 0.08$ and $4.74 \pm 0.14 \mu \mathrm{mol} / \mathrm{g}$ for T1, T2, $\mathrm{T} 3$, and T4, respectively, compared to control sample $2.23 \pm 0.14 \mu \mathrm{mol} / \mathrm{g}$. The sensory characteristics (appearance, crust color, crumb color, crumb distribution, taste, flavor and overall acceptability) of produced pan bread were evaluated. The results indicated that the sensory properties were decreased with substituted levels of PPP and PSP powder compared to control sample. Staling of produced pan bread was estimated at zero time and after storage periods $(24,48$ and $72 \mathrm{hrs}$.) and the results indicated that staling was increased as the pomegranate peel and seed addition level increased, it was decreased during storage period in all pan bread samples. The results showed that PPP and PSP fortified loaves were lower in loaf volume and higher in loaf weight compared with control sample, while the loaf volume of $18 \%$ PPP and PSP fortified bread was $341.67 \pm 17.64\left(\mathrm{~cm}^{3}\right)$ control sample was $435.00 \pm 15.28\left(\mathrm{~cm}^{3}\right)$ with $21.4 \%$ reduction. The water absorption of wheat flour was gradually increasedwithincreasing the level of PPP powder while,dough development time (min) in samples with PPP and PSP lightly increase with increasing substitution level. Dough stability time was decreased from $10.10 \mathrm{~min}$. for control sample to $4.90 \mathrm{~min}$ for $18 \%$ PPP and PSP, respectively. The degree of dough weakening increasedwith increasing of substitution level.
\end{abstract}

Key words: Pomegranatepeel, seed powder and Pan bread.

\section{Introduction}

The pomegranate fruit (Punica grantum L.) could be considered a functional food because it has valuable compounds in different parts of the fruit that display functional and medicinal effects. Pomegranate fruits peel is an inedible part obtained during processing of pomegranate juice.Pomegranate peel is a rich source of tannins, flavonoids and other phenolic compounds. Due to the large amount of pomegranate seeds as the by-product of juice and concentrate production plants and because of valuable pharmaceutical and nutritional compounds such as unsaturated fatty acids and phenolic compounds in the seed and their antioxidant properties, the seeds can have more beneficial applications in food industries(Li et al., 2006 and Mohagheghi et al., 2011).

Pan bread is one of the most widely consumed grain products in the world. Whole-wheat flour (WWF) pan bread is preferred by more consumers because of its high dietary fiber and bioactive substances, which not only reduce cholesterol levels but also decrease the risk of colon cancer (Okarter and Liu, 2010). To meet the growing demand for healthy and lowcalorie foods, the development of bread products made with WWF, with its high content of dietary fiber and unsaturated fatty acids, could be an effective way to promote high-fiber food consumption and improve dietary patterns (Mozaffarian et al., 2013 andNiu etal., 2014). However, the unsaturated fatty acids in WWF are susceptible to oxidation under high temperature and/or light conditions, which decreases the nutritional value and makes the product unpalatable. The overall anti-oxidative capacity of whole wheat bread was reduced during storage as the lipid hydro peroxides were peaked after 2-3 weeks of storage (Jensen et al., 2011).

Dietary fibers are beneficial for health maintenance and disease prevention. Regular fiber intake helps to prevent obesity, cardiovascular diseases, type 2 diabetes, metabolic syndrome and constipation (Slavin, 2008; Mello and Laaksonen, 2009 and Holma et al., 2010). The addition of fiberrich ingredients to the dough causes changes in water absorption and quality of the bread (Sluimer, 2005). 
The main objectives of this study were to investigate the possibility tousing the pomegranate peel and seed powder as partially substitute for wheat flour on some physical, chemical and quality attributes of pan bread.

\section{Materials And Methods}

\subsection{Materials:}

Pomegranate fruits (Punicagranatum L.) namely: Manfalouty were obtained from Manfalut city, Assiut Governorate, Egypt. Wheat flour (WF)extracting rate $72 \%$ was obtained from Egyptian National Company for Grinding and Food Industries, extension of $3^{\text {rdindustrial }}$ zone $-6^{\text {th }}$ of October, Egypt.Other ingredients for baking process, i.e., compressed yeast, sugar and salt were purchased from local market, Cairo, Egypt.

\subsection{Methods:}

\subsubsection{Processing of pomegranate peels and seeds} powder:

The peels and seeds were manually separated. The seeds were washed with excess water for the removal the sugars. The required fruits rind were (pomegranate peel) cut into small pieces and removed from the fruits. The fruits rind and seedswere dried in an oven at $40^{\circ} \mathrm{C}$ for $24 \mathrm{hrs}$ (Mehder, 2013) then mechanically powdered and the fine powder was sieved through $24-m e s h$, then it was stored at $-18^{\circ} \mathrm{C}$ until use.

\subsubsection{Processing of pan bread:}

Pan bread treatmentsprepared by different levels of PPP and PSP. The ratios which had high score in sensory evaluation were used for preparing finished pan bread treatments which used to complete this study.

The straight dough method for pan bread production was carried out according to the method described by A.A.C.C (2000) as described in Table (1).The ingredients were mixed thoroughly by hand for one minute, then the dough was further mixed in a laboratory mixer for approximately 4 minutes. The dough was put into a greased fermentation bowl, and then cut, rolled and placed in a fermentation cabinet for 50 minutes at $37 \pm 2^{\circ} \mathrm{C}$ and $80-85 \%$ relative humidity. Then baked in an electric oven at about $220 \pm 8^{\circ} \mathrm{C}$ for 25 minutes. After baking loaves were separated from the metal pan and allowed to cool at room temperature $35^{\circ} \mathrm{C}$ before sensory evaluation. The produced pan bread was measured each of weight, volume and chemical composition. PSP used as source of oil instead of corn oil.

Table 1. Pan bread treatments fortified with different levels of PPP and PSP

\begin{tabular}{ccccccccc}
\hline Treatments & $\begin{array}{c}\text { WF } \\
(\%)\end{array}$ & $\begin{array}{c}\text { PPP } \\
(\%)\end{array}$ & $\begin{array}{c}\text { PSP } \\
(\%)\end{array}$ & $\begin{array}{c}\text { Salt } \\
(\%)\end{array}$ & $\begin{array}{c}\text { Compressed } \\
\text { Yeast }(\%)\end{array}$ & $\begin{array}{c}\text { Sugar } \\
(\%)\end{array}$ & $\begin{array}{c}\text { Corn oil } \\
(\%)\end{array}$ & $\begin{array}{c}\text { Improver } \\
(\%)\end{array}$ \\
\hline Control & 100 & - & - & 1.0 & 1.5 & 1.5 & 1.5 & 1.0 \\
T1 $(6 \%)$ & 94 & 2 & 4 & 1.0 & 1.5 & 1.5 & 0.85 & 1.0 \\
T2 $(9 \%)$ & 91 & 3 & 6 & 1.0 & 1.5 & 1.5 & $\mathbf{0 . 5 2 0}$ & 1.0 \\
T3 $(13.5 \%)$ & 86.5 & 4.5 & 9 & 1.0 & 1.5 & 1.5 & $\mathbf{0 . 0 3 0}$ & 1.0 \\
T4 $(18 \%)$ & 82 & 6 & 12 & 1.0 & 1.5 & 1.5 & - & 1.0 \\
\hline
\end{tabular}

WF: Wheat flour, PPP: Pomegranate peel powder, PSP:Pomegranate seed powder.

\subsection{Analytical methods}

2.3.1.Proximate chemical analysis:

The moisture, ash, fat, protein, crude fiber contents and Ascorbic acid content were determined according to the method described byA.O.A.C(2012).Available carbohydrate was calculated by differences.Total phenolic content of each sample was determined using a FolinCiocalteu assay according to the method of Singleton (1965).Total flavonoid content was measured by $\mathrm{AlCl}_{3}$ colorimetric assay according to the method of Tacouri et al. (2013). The total anthocyanins content in the extract from fruits was estimated by Giusti and Wrolstad (2001).Total tannin content was quantified according to Makkar $\boldsymbol{e t}$ al. (2007). The radical scavenging ability of samples was determined in the samples according to $\mathbf{L u}$ et al.(2007)

\subsubsection{Rheological properties:}

Mixing and pasting behaviour of dough was studied using the Mixolab analyzer (Chopin, Tripette et Renaud, Paris, France, Version4.0.8+3.50A) and Specific volume were determined according to the method described by A.A.C.C (2010). Alkaline water retention capacity was determinated according to the method mentioned by Yamazaki (1953) and Kitterman and Rubenthaler (1971).

\subsubsection{Sensory evaluation of pan bread:}

Samples of pan bread were evaluated by 20 panelists (staff members and students from the Food Technology Department, Faculty of Agriculture, Benha University, were asked to evaluate the prepared pan bread towards) for appearance (20), color of crust (15), color of crumb (15), crumb distribution (15) taste (20), flavor (15), and overallacceptability (100). The total value of these sensory properties was evaluated as overall acceptability and descriptive category as follows: 90-100: very good, 80-89: good, 70-79: satisfactory and less than 70: questionable Khorshid et al. (2011).

\subsubsection{Statistical analysis:}

The statistical analysis was carried out using SPSS program with multi-function utility regarding to the experimental design under significance level of 0.05 
for the whole results and multiple comparisons were carried out applying LSD according to Steelet al.(1997).

\section{Results And Discussion}

3.1. Chemical composition of pomegranate peel powder (PPP), pomegranate seed powder (PSP) and wheat flour

As shown in Table (2), the moisture content of produced pomegranate peels and seeds powderwere found to be $11.27 \pm 0.21$ and $3.30 \pm 0.07 \%$; respectively. In addition, ash, crude protein, ether extract, crude fibers and available carbohydrate contents for pomegranate peels powder (PPP) were $5.06 \pm 0.04,4.71 \pm 0.07,0.83 \pm 0.10,16.59 \pm 0.32$ and $72.81 \pm 0.35 \%$, versus, $2.57 \pm 0.07, \quad 8.51 \pm 0.2$, $17.03 \pm 0.20, \quad 28.18 \pm 0.20$ and $43.70 \pm 0.34 \%$ for pomegranate seeds powder (PSP)(on dry weight basis); respectively. According to this findings, the (PPP) is a good source of crude fibers, ash and carbohydrates, while (PSP) is a good source of crude protein, fat and fibers.These results are in agreement with those obtained by Hassan et al. (2012) who found that the seed oil content in pomegranate "Manfalouty" in Egypt was $16.63 \%$ and these results coincide with the data obtained by Rowayshed et al. (2013) and Dadashi et al. (2013) who found oil content ranged from $13.5 \pm 0.08$ to $16.9 \pm 0.11$ and crude protein ranged from $8.5 \pm 0.029$ to $11.3 \pm 0.064$ for seeds obtained from four Iranian commercial pomegranate varieties.

The results from Table (2) indicated that moisture, ash, protein, fat, fiber and available carbohydrate content for wheat flour $72 \%$ was $10.28 \pm 0.13$, $0.57 \pm 0.08, \quad 9.47 \pm 0.21, \quad 1.47 \pm 0.15, \quad 1.11 \pm 0.10$ and $87.38 \pm 0.16 \%$, respectively. These results are in accordance with Hefnawyet al.(2012).

Table 2. Proximate chemical composition of dried pomegranate peel, seed powder and wheat flour (72\% ext.) $($ mean \pm SE).

\begin{tabular}{|c|c|c|c|}
\hline Components (\%) & Peel & Seed & Wheat flour (72\% ext.) \\
\hline Moisture & $11.27 \pm 0.21$ & $3.30 \pm 0.07$ & $10.28 \pm 0.13$ \\
\hline Total solids & $88.73 \pm 0.21$ & $96.70 \pm 0.07$ & $89.72 \pm 0.01$ \\
\hline Ash $*$ & $5.06 \pm 0.04$ & $2.57 \pm 0.07$ & $0.57 \pm 0.08$ \\
\hline Crude protein* & $4.71 \pm 0.07$ & $8.51 \pm 0.2$ & $9.47 \pm 0.21$ \\
\hline Ether extract* & $0.83 \pm 0.10$ & $17.03 \pm 0.20$ & $1.47 \pm 0.15$ \\
\hline Crude fiber* & $16.59 \pm 0.32$ & $28.18 \pm 0.20$ & $1.11 \pm 0.10$ \\
\hline Available carbohydrate*@ & $72.81 \pm 0.35$ & $43.71 \pm 0.34$ & $87.38 \pm 0.16$ \\
\hline
\end{tabular}

Ascorbic acid, total phenolic compounds, total tannins, total flavonoids, anthocyanin andantioxidant activity of PPP and PSP are presented in Table (3). The results indicated that Vit. $\mathrm{C}$ content was $24.91 \pm 0.06$ and $4.37 \pm 0.00 \mathrm{mg} / 100 \mathrm{~g}$, the total phenolic content $192.30 \pm 0.46$ and $1.69 \pm 0.00 \mathrm{mg}$ $\mathrm{GAE} / \mathrm{g}$, total tannins content was $4.30 \pm 0.01$ and $0.54 \pm 0.00 \%$, total flavonoids content was $46.18 \pm 0.11$ and $1.25 \pm 0.03 \mathrm{mg} / \mathrm{g}$, anthocyanin content was $73.78 \pm 0.18$ and $6.57 \pm 0.28 \mathrm{mg} / 100 \mathrm{~g}$, and antioxidant activity $778.24 \pm 10.17$ and $50.11 \pm 1.37 \mu \mathrm{mol} / \mathrm{gfor}$ PPP and PSP, respectively (on dry weight basis). These results nearly coincide with the results previously obtained byLiet al.(2006) and Elgindy and Elsarha (2015).These differences in chemical composition may be attributed to the variability of varieties and especially to the origin of cultivars. Differences observed for the same cultivar are due mainly to the climate conditions, harvesting period, and storage conditions Metouiet al. (2019).

Table 3. Bio-chemical components of pomegranate peel and seed powder (mean $\pm \mathrm{SE}$ ).

\begin{tabular}{|c|c|c|}
\hline Components & Peel & Seed \\
\hline Vit. C (mg/100g)* & $24.91 \pm 0.06$ & $4.37 \pm 0.00$ \\
\hline Total phenols (mg/g)* & $192.30 \pm 0.46$ & $1.69 \pm 0.00$ \\
\hline Total tannins $(\%)^{*}$ & $4.30 \pm 0.01$ & $0.54 \pm 0.00$ \\
\hline Total flavonoides (mg/g)* & $46.18 \pm 0.11$ & $1.25 \pm 0.03$ \\
\hline Anthocyanin (mg/100 g)* & $73.78 \pm 0.18$ & $6.57 \pm 0.28$ \\
\hline Antioxidant activity $(\mu \mathrm{mol} / \mathrm{g})^{*}$ & $778.24 \pm 10.17$ & $50.11 \pm 1.37$ \\
\hline
\end{tabular}


3.2. Effect of pomegranate peels and seeds powder on rheological properties of wheat flour dough using Mixolab apparatus:

The results presented in Table (4) and illustrated in Figure (1) showed the effect of substitution of wheat flour (72\% ext.) with 6, 9, 13.5 and $18 \%$ of PPP and PSP on Mixolab parameters. As it can be seen in Table (4) and Fig. (1), the first part of the Mixolab curve refers to the protein characteristics of the systems and it is characterized determination of the following parameters: water absorption (WA); dough development time; dough development (C1); dough stability and $\mathrm{C} 2$ value which is related to the protein weakening due to mechanical and thermal constraints. From the obtained data, it could be noticed that the water absorption of wheat flour was gradually increased as the level of PPP and PSP increased which reached to 57.9, 58.2, 58.4 and $59.0 \%$ for wheat flour dough's replaced with $6,9,13.5$ and $18 \%$ of PPP and PSP, respectively compared to $57.4 \%$ for the control wheat flour dough. The increased in water absorption of the dough which prepared by using PPP and PSP probably due to the higher fiber content of PPP and PSP than wheat flour. These results are in agreement with those reported by Abd El-Moniem and Yassen (1993) they reported that, addition of fiber sources to wheat flour caused an increased in water absorption of the produced dough. This may be due to higher water hydration capacity of fibers Chen $\boldsymbol{e t}$ al. (1988).

Also, from the same Table (4) it could be observed that, dough development time ( $\mathrm{min})$ in treatment samples with PPP and PSP slightly increased from 7.35 to $9.27 \mathrm{~min}$ as the substitution level was increasing from 6 to $9 \%$, respectively,

while, dough development time for control sample was $1.38 \mathrm{~min}$. As for dough development $(\mathrm{C} 1)$ the results indicated that by increasing the substitution levels of wheat flour by PPP and PSP, the dough development increase in all flour blends. These results may be related to increasing level of PPP and PSP which more time required for complete hydration of the material, and could be related to the composition and characteristics of protein and starch.

Table 4. Rheological properties of wheat flour dough using Mixolab apparatus.

\begin{tabular}{|c|c|c|c|c|c|c|c|c|c|c|}
\hline \multirow[b]{2}{*}{$\begin{array}{l}\text { Treat- } \\
\text { ments }\end{array}$} & \multicolumn{6}{|c|}{ Mixing properties } & \multicolumn{4}{|c|}{ Pasting ability behavior } \\
\hline & $\begin{array}{c}\text { Water } \\
\text { absorpt } \\
\text { ion }(\%)\end{array}$ & $\begin{array}{c}\text { Develop } \\
\text {-ment } \\
\text { time } \\
(\mathrm{min})\end{array}$ & $\begin{array}{l}\text { Dough } \\
\text { Stabilit } \\
\text { y (min) }\end{array}$ & $\begin{array}{c}\text { Dough } \\
\text { developme } \\
\text { nt } \\
\text { C1 }(\mathbf{N m})\end{array}$ & $\begin{array}{c}\begin{array}{c}\text { Protein } \\
\text { breakdow } \\
n \\
\text { C2 }(\mathrm{Nm})\end{array}\end{array}$ & $\begin{array}{c}\text { Protein } \\
\text { weakenin } \\
\text { g }(\mathrm{C} 1-\mathrm{C} 2) \\
(\mathrm{Nm})\end{array}$ & $\begin{array}{c}\text { Starch } \\
\text { gelatinizat } \\
\text {-ion C3 } \\
\text { (Nm) }\end{array}$ & $\begin{array}{l}\text { Amylase } \\
\text { activity } \\
\text { C4 (Nm) }\end{array}$ & $\begin{array}{c}\text { Starch } \\
\text { gelling } \\
\text { Or } \\
\text { Final } \\
\text { torque } \\
\text { C5 } \\
\text { (Nm) }\end{array}$ & $\begin{array}{c}\text { Set } \\
\text { back } \\
\text { torque } \\
\text { (C5- } \\
\text { C4) } \\
\text { (Nm) }\end{array}$ \\
\hline Control & 57.4 & 1.38 & 10.10 & 1.127 & 0.565 & 0.562 & 1.849 & 2.253 & 3.280 & 1.027 \\
\hline T1 & 57.9 & 7.35 & 10.92 & 1.107 & 0.441 & 0.666 & 1.631 & 1.959 & 3.207 & 1.248 \\
\hline $\mathbf{T 2}$ & 58.2 & 9.27 & 11.55 & 1.125 & 0.459 & 0.666 & 1.701 & 1.957 & 3.273 & 1.316 \\
\hline T3 & 58.4 & 0.62 & 3.25 & 1.101 & 0.595 & 0.506 & 1.919 & 1.864 & 3.242 & 1.378 \\
\hline T4 & 59.0 & 0.62 & 4.90 & 1.061 & 0.581 & 0.480 & 1.836 & 1.119 & 3.027 & 1.908 \\
\hline
\end{tabular}

Dough stability time is an important index for the dough strength based on the quality of dough gluten, so it could be observed that, the stability time of composite wheat flour dough with 6, 9, 13.5 and $18 \%$ of PPP and PSP was increased from $10.10 \mathrm{~min}$ for control sample to 11.55 min for $9 \%$ PPP and PSP, while decreased to 4.90 min for $18 \%$ of PPP and PSP. The decrement in the stability time indicates weakness of dough strength. This weakness of the dough may be due to using PPP and PSP which reduced the wheat gluten content (dilution effect) in the treatments which make the dough more weak strength.

Concerning the degree of minimum torque (C2) or dough breakdown as shown in Table (4), it could be remarked that the degree of dough weakening increased as the substitution level with PPP and PSP increased. This values were increase from 0.414 to $0.581 \mathrm{Nm}$ when the substitution levels was increasing from 6 to $18 \%$ of PPP and PSP as compared to 0.565 $\mathrm{Nm}$ in control sample. In addition, Protein weakening was increased from 0.562 for control sample to 0.666 $\mathrm{Nm}$ when the substitution levels were increasing to 9\% PPP and PSP.
Second part of the Mixolab curves reveals the starch properties of tested systems. More attention was paid on the first peak at $\mathrm{C} 3$ point which is the measure of starch gelatinization and the difference between the $\mathrm{C} 5$ and $\mathrm{C} 4$ value which represents starch retrogradation degree (Bonet et al., 2006 and Ozturk et al., 2008). Results in Table (4) and Figure (1), indicate that wheat flour starch behavior was characterized by the highest gelling ability as it was manifested by the value of starch gelatinization (torque at C3) point, while, increasing the amount of PPP and PSP in tested dough samples led to gradual increase in the values of starch gelatinization (torque at $\mathrm{C} 3$ point), which were increased from 1.631 to $1.919 \mathrm{Nm}$ when the substitution levels of pomegranate peels powder increased from 6 to $13.5 \%$, respectively, as compared to $1.849 \mathrm{Nm}$ in control sample. Regarding amylase activity (C4) and starch gelling (C5), as shown in Table (4), amylase activity (C4) and starch gelling (C5) decreased as the partial replacement of PPP and PSP increased from 6 to $18 \%$ in flour treatment, whereas it was ranged between 1.959 to $1.119 \mathrm{Nm}$ for amylase activity (C4) and progressively decreased from 3.207 to $3.027 \mathrm{Nm}$ for 
starch gelling (C5) as the replacement rate increased from 6 to $18 \%$ of PPP and PSP in the wheat flour treatment compared with 2.253 and $3.280 \mathrm{Nm}$ in control sample, respectively. In addition, set back values ranged between 1.248 to $1.908 \mathrm{Nm}$ as the substitution levels were increasing from 6 to $18 \%$ PPP and PSP in comparison with control sample $(100 \%$ wheat flour $72 \%$ ext.) which recorded $1.027 \mathrm{Nm}$.

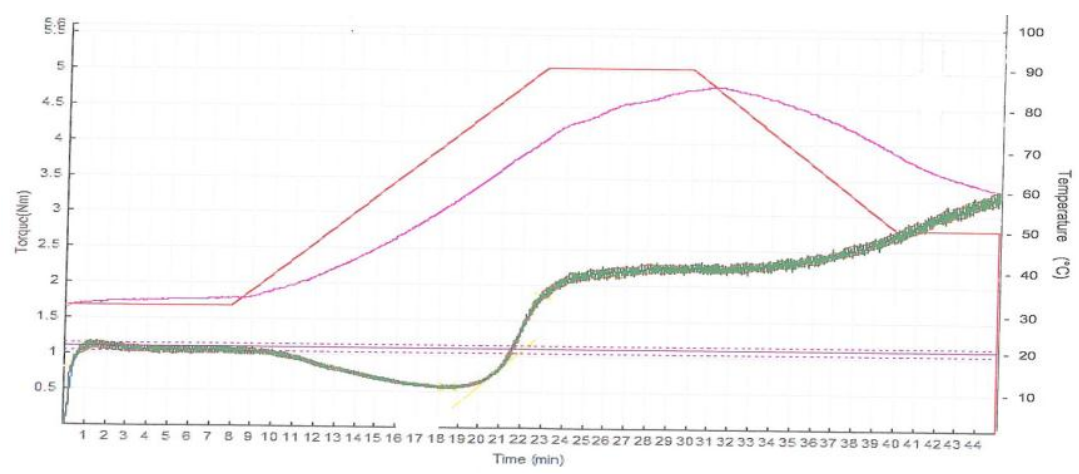

Control (100\% wheat flour)

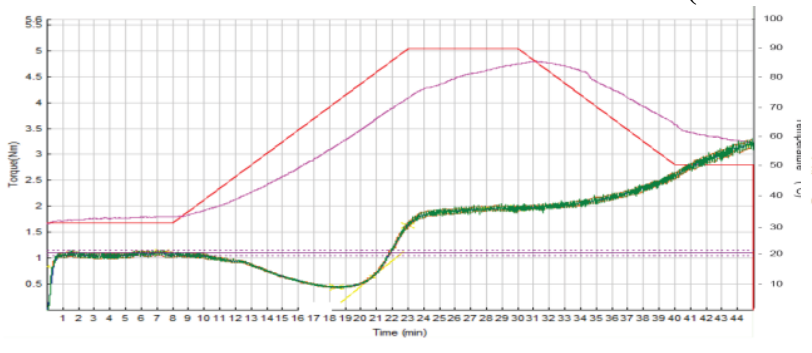

T1 (2\% PPP + 4\% PSP)

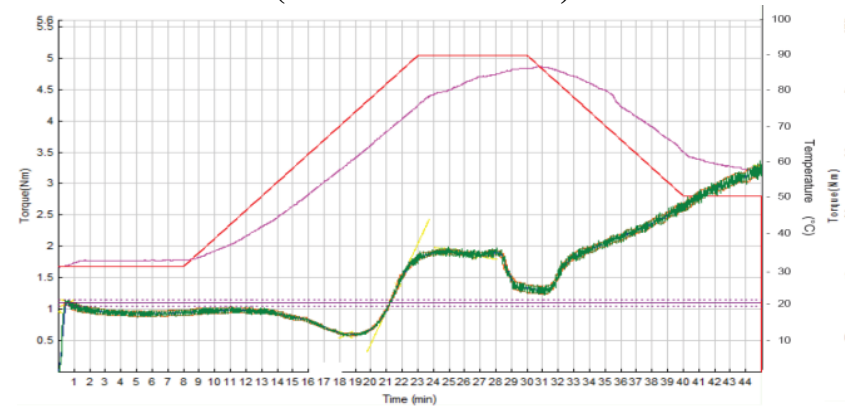

T3 (4.5\% PPP + 9\% PSP)

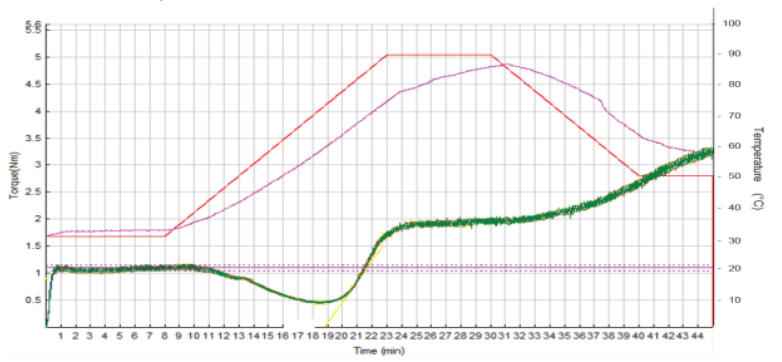

T2 (3\% PPP + 6\% PSP)

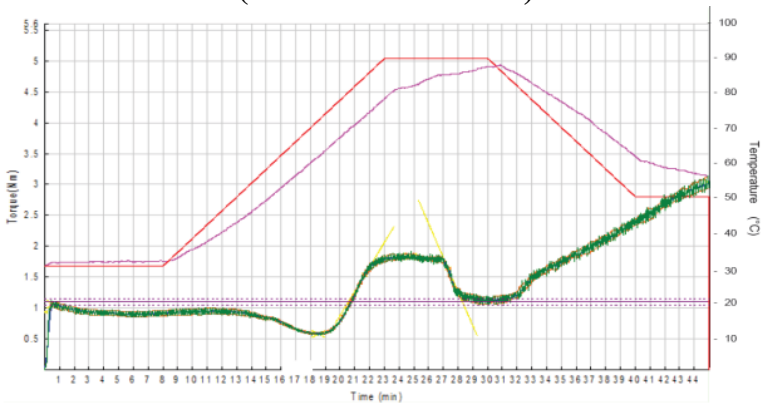

T4 (6\% PPP + 12\% PSP)

Fig. (1): Mixolab torque curves of wheat flour dough with PPP and PSP.

\subsection{Proximate chemical composition of produced pan bread.}

Chemical composition of pan bread fortified with different levels T1 (6\%), T2 (9\%), T3 (13.5\%) and T4 $(18 \%)$ of pomegranate peel and seed powder compared with control treatment (wheat flour 100\%) are presented in Table (5). These results showed that nonsignificant difference $(\mathrm{P}>0.05)$ in moisture and total solids content between all treatments. The lower value of moisture recorded by control sample $31.03 \pm 0.99 \%$ while, the maximum value recorded by T4 $33.88 \pm 1.53 \%$. Non significant increase in protein content at the level of 6 and 9\% PPP and PSP fortified pan bread $17.70 \pm 0.39 \%, 18.18 \pm 0.51 \%$ and control sample $16.80 \pm 0.16 \%$, while significant increases in protein content were found at the level of $13.5 \%$ and $18 \%$ (PPP) and (PSP) fortified pan bread was $18.67 \pm 0.55$ and $19.55 \pm 0.47 \%$, respectively compared with control sample. On the other hand, significant increases $4.76 \pm 0.09, \quad 4.78 \pm 0.07,4.84 \pm 0.20$ and $6.59 \pm 0.44$ of ether extract content were observed at the levels of 6, 9, 13.5 and $18 \%$ of (PPP) and (PSP) in fortified pan bread, respectively compared with control sample $1.91 \pm 0.02$. Non significant increase in ash content at the level of 6 and 9\% PPP and PSP fortified pan bread $1.76 \pm 0.07 \%, 1.76 \pm 0.02 \%$ and control sample $1.68 \pm 0.06 \%$. While, significant increases in ash content were found at the level of 13.5 and $18 \%$ (PPP) and (PSP) in fortified pan bread, $1.99 \pm 0.05 \%$ and $2.11 \pm 0.03 \%$, respectively compared 
with control sample. Crude fiber content was significant increase by increasing the level of PPP and PSP reach the maximum value $7.29 \pm 0.08 \%$ at the level of $18 \%$ of PPP and PSP fortified bread compared with control sample $0.99 \pm 0.03 \%$.

Table 5. Proximate chemical composition of produced pan bread fortified with different levels of PPP and PSP. (g/100 g on dry basis) (mean \pm SE).

\begin{tabular}{|c|c|c|c|c|c|c|c|}
\hline \multirow[b]{2}{*}{ Treatment } & \multicolumn{7}{|c|}{ Component } \\
\hline & $\begin{array}{c}\text { Moisture } \\
(\%)\end{array}$ & $\begin{array}{l}\text { Total } \\
\text { solid } \\
(\%) \\
\end{array}$ & $\begin{array}{c}\text { Crude } \\
\text { protein } \\
(\%)\end{array}$ & $\begin{array}{c}\text { Ether } \\
\text { extract } \\
(\%)\end{array}$ & $\begin{array}{l}\text { Ash } \\
(\%)\end{array}$ & $\begin{array}{c}\text { Crude } \\
\text { fiber }(\%)\end{array}$ & $\begin{array}{c}\text { Available } \\
\text { carbohyd- } \\
\text { rate }(\%)\end{array}$ \\
\hline \multirow[t]{2}{*}{ Control } & 31.03 & 68.97 & 16.80 & 1.91 & 1.68 & 0.99 & 78.62 \\
\hline & $\pm 0.99^{a}$ & $\pm 0.99^{a}$ & $\pm 0.16 c$ & $\mathbf{\pm 0 . 0 2 ^ { c }}$ & $\pm 0.06^{b}$ & $\pm 0.03^{e}$ & $\pm 0.18^{a}$ \\
\hline \multirow[t]{2}{*}{$\mathbf{T 1}$} & 33.26 & 66.74 & 17.70 & 4.76 & 1.76 & 3.42 & 72.36 \\
\hline & $\pm 1.77^{\mathrm{a}}$ & $\pm 1.77^{\mathrm{a}}$ & $\pm 0.39^{b c}$ & $\pm 0.09^{b}$ & $\pm 0.07^{b}$ & $\pm 0.05^{d}$ & $\pm 0.57^{b}$ \\
\hline \multirow[t]{2}{*}{$\mathbf{T} 2$} & 31.11 & 68.89 & 18.18 & 4.78 & 1.76 & 4.07 & 71.21 \\
\hline & $\pm 1.34^{\mathrm{a}}$ & $\pm 1.34^{\mathrm{a}}$ & $\pm 0.51^{a b c}$ & $\pm 0.07^{b}$ & $\pm 0.02^{b}$ & $\pm 0.08^{c}$ & $\pm 0.54^{b}$ \\
\hline \multirow[t]{2}{*}{ T3 } & 33.44 & 66.56 & 18.67 & 4.84 & 1.99 & 5.93 & 68.57 \\
\hline & $\pm 1.89^{a}$ & $\pm 1.89^{a}$ & $\pm 0.55^{\mathrm{ab}}$ & $\pm 0.20^{b}$ & $\pm 0.05^{a}$ & $\pm 0.20^{b}$ & $\pm 0.99^{c}$ \\
\hline \multirow[t]{2}{*}{ T4 } & 33.88 & 66.12 & 19.55 & 6.59 & 2.11 & 7.29 & 64.46 \\
\hline & $\pm 1.53^{\mathrm{a}}$ & $\pm 1.53^{\mathrm{a}}$ & $\pm 0.47^{\mathrm{a}}$ & $\pm 0.44^{\mathrm{a}}$ & $\pm 0.03^{a}$ & $\pm 0.08^{a}$ & $\pm 0.72^{d}$ \\
\hline
\end{tabular}

a, b \& c: There is no significant difference $(\mathrm{P}>0.05)$ between any two means, within the same column have the same superscript letter.

On the contrary, significant decrease of available carbohydrate content was observed by increasing in PPP and PSP levels to reach the minimum value $64.46 \pm 0.72 \%$ at level $18 \%$ compared with control sample $78.62 \pm 0.18 \%$. Similar results with agreement those obtained by Mehder (2013) and Sayed-Ahmed (2014) they reported that the addition of PPP in pan bread was increased ash, fiber and fat contents, while decreased the protein and carbohydrate contents. In this study addition of PSP was increased protein content in pan bread this may be due to the protein content in PPP and PSP higher than wheat flour.

\subsection{Bio-chemical components of pan bread (on dry basis) (mean \pm SE).}

Total phenolic, total flavonoids contents and antioxidants activity of pan bread are presented in Table (6). The results indicated that a significant increases in total phenolic, total flavonoids and antioxidant activity. The $\mathrm{T} 4$ recorded the highest significant values $34.99 \pm 0.84 \mathrm{mg} / \mathrm{g}, 7.62 \pm 0.28 \mathrm{mg} / \mathrm{g}$ and $4.74 \pm 0.14 \mu \mathrm{mol} / \mathrm{g}$ from three compounds, respectively, while the control sample recorded the lowest scores $14.26 \pm 0.23 \mathrm{mg} / \mathrm{g}, 4.44 \pm 0.06 \mathrm{mg} / \mathrm{g}$ and $2.23 \pm 0.14 \mu \mathrm{mol} / \mathrm{g}$ for total phenolic, total flavonoids and antioxidant activity,respectively.

Table 6. Bio-chemical components of produced pan bread fortified with different levels of PPP and PSP. $($ mean \pm SE).

\begin{tabular}{|c|c|c|c|}
\hline \multirow{2}{*}{ Treatment } & \multicolumn{3}{|c|}{ Component } \\
\hline & Total phenolic (mg/g) & Total flavonids (mg/g) & Antioxidants activity $(\mu \mathrm{mol} / \mathrm{g})$ \\
\hline Control & $14.26 \pm 0.23^{d}$ & $4.44 \pm 0.06^{d}$ & $2.23 \pm 0.14^{d}$ \\
\hline $\mathbf{T 1}$ & $26.48 \pm 0.89^{c}$ & $5.64 \pm 0.10^{c}$ & $2.69 \pm 0.20^{c}$ \\
\hline $\mathbf{T} 2$ & $28.84 \pm 0.59^{c}$ & $5.72 \pm 0.28^{c}$ & $3.29 \pm 0.13^{b}$ \\
\hline T3 & $31.78 \pm 1.12^{b}$ & $6.66 \pm 0.39^{b}$ & $4.31 \pm 0.08^{a}$ \\
\hline $\mathbf{T 4}$ & $34.99 \pm 0.84^{a}$ & $7.62 \pm 0.28^{a}$ & $4.74 \pm 0.14^{a}$ \\
\hline
\end{tabular}

a, b \& c: There is no significant difference $(\mathrm{P}>0.05)$ between any two means, within the same column have the same superscript letter.

From the data presented in Table (6)it could be noticed that, the pan bread with PPP and PSP is a good source of total phenolic, total flavonoids and antioxidant activity. These are in results agreement with those obtained by (Mehder, 2013) .

\subsection{Sensory evaluation of pan bread:}

The sensorycharacteristicssuch as: appearance, crust color, crumb color, crumb distribution, Taste, flavor and overall acceptability of pan bread partially substituted of wheat flour with PPP and PSP levels (6, 9, 13.5 and $18 \%$ ) were evaluated. The means sensory scores of pan bread partially substituted of wheat flour with PPP and PSP are presented in Table (7). From the obtained data it could be seen that there was a significant difference between control and treatments (T1:T4) for tested sensorycharacteristics (appearance, crust color, crumb color (see fig: 2) and overall acceptability, while non significant difference between control sample andpan bread treatments for sensory evaluation such as: taste and flavor for all treatments except T4 there is a significant difference between it and control in taste. This taste may be due to increase the PPP to $6 \%$ it could be affected on the taste. 


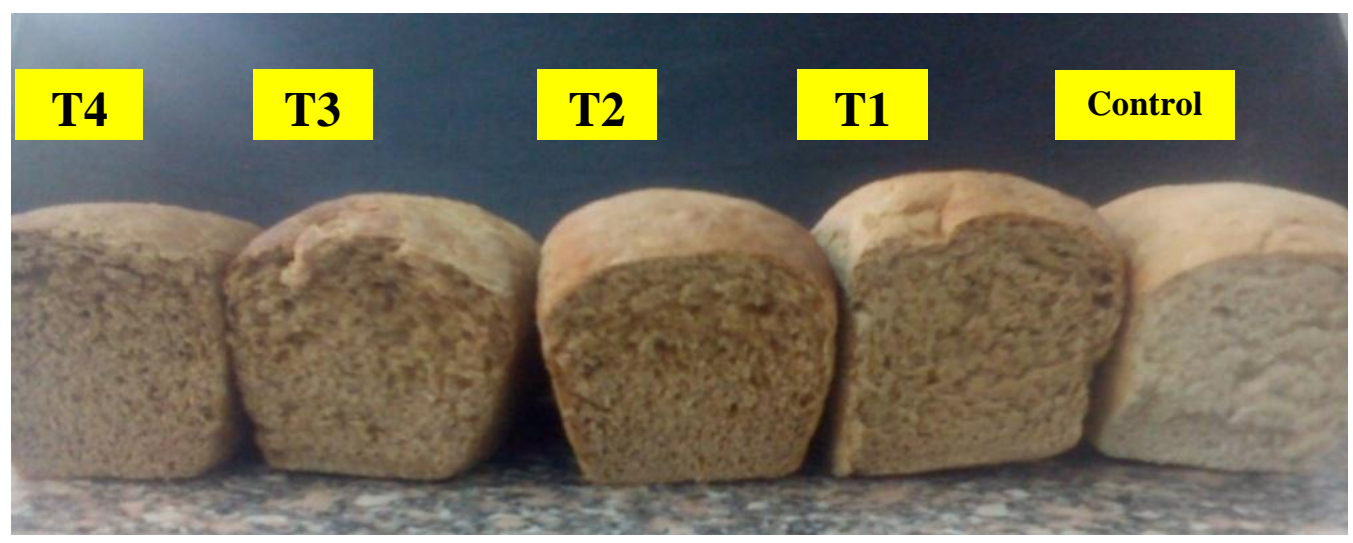

Fig. (2): Pan bread treatments.

On the other hand, the results indicated that there is non significant difference between all treatments in appearance, crust color, taste, flavor and overall acceptability while there is a significant difference between $\mathrm{T} 4$ and other treatments in color crumb and overall acceptability. The results from Table (7) showed that the highest significant scoresfor the sensoryevaluation were $17.48 \pm 0.41,13.81 \pm 0.22$,
$13.90 \pm 0.18, \quad 13.14 \pm 0.29, \quad 15.95 \pm 0.52, \quad 12.71 \pm 0.55$ $86.99 \pm 1.27$ in control sample while the lowest significant scores were $14.29 \pm 0.66,11.67 \pm 0.34$, $11.19 \pm 0.31,11.57 \pm 0.41,13.81 \pm 0.76,12.43 \pm 0.30$ and $74.95 \pm 2.19$ in T4 for appearance, crust color, crumb color, crumb distribution, taste, flavor and overall acceptability respectively.

Table 7. Sensory evaluation of produced pan bread fortified with different levels of PPP and PSP. (mean \pm SE).

\begin{tabular}{|c|c|c|c|c|c|c|c|}
\hline \multirow[b]{2}{*}{ Treatment } & \multicolumn{7}{|c|}{ Attribute } \\
\hline & $\begin{array}{c}\text { Appearance } \\
(20) \\
\end{array}$ & $\begin{array}{c}\text { Crust } \\
\text { color } \\
(15) \\
\end{array}$ & $\begin{array}{c}\text { Crumb } \\
\text { color } \\
(15) \\
\end{array}$ & $\begin{array}{c}\text { Crumb } \\
\text { distribution } \\
(15)\end{array}$ & $\begin{array}{l}\text { Taste } \\
\text { (20) } \\
\end{array}$ & $\begin{array}{c}\text { Flavor } \\
\text { (15) }\end{array}$ & $\begin{array}{c}\text { Overall } \\
\text { acceptability } \\
(\mathbf{1 0 0})\end{array}$ \\
\hline Control & $17.48 \pm 0.41^{\mathrm{a}}$ & $13.81 \pm 0.22^{a}$ & $13.90 \pm 0.18^{a}$ & $13.14 \pm 0.29^{a}$ & $15.95 \pm 0.52^{a}$ & $12.71 \pm 0.55^{a}$ & $86.99 \pm 1.27^{a}$ \\
\hline T1 & $15.43 \pm 0.49^{b}$ & $12.29 \pm 0.28^{b}$ & $12.19 \pm 0.24^{b c}$ & $12.38 \pm 0.33^{a b}$ & $15.05 \pm 0.56^{\mathrm{ab}}$ & $12.71 \pm 0.28^{a}$ & $80.05 \pm 1.52^{b}$ \\
\hline $\mathbf{T 2}$ & $15.90 \pm 0.52^{b}$ & $12.24 \pm 0.35^{b}$ & $12.43 \pm 0.27^{b}$ & $12.71 \pm 0.34^{\mathrm{a}}$ & $15.38 \pm 0.54^{\mathrm{ab}}$ & $12.81 \pm 0.31^{\mathrm{a}}$ & $81.47 \pm 1.56^{b}$ \\
\hline T3 & $15.24 \pm 0.62^{b}$ & $11.76 \pm 0.29^{b}$ & $11.67 \pm 0.23^{\mathrm{cd}}$ & $12.24 \pm 0.29^{\mathrm{ab}}$ & $14.86 \pm 0.63^{a b}$ & $12.48 \pm 0.34^{\mathrm{a}}$ & $78.25 \pm 1.93^{b c}$ \\
\hline T4 & $14.29 \pm 0.66^{b}$ & $11.67 \pm 0.34^{b}$ & $11.19 \pm 0.31^{d}$ & $11.57 \pm 0.41^{b}$ & $13.81 \pm 0.76^{b}$ & $12.43 \pm 0.30^{\mathrm{a}}$ & $74.95 \pm 2.19^{c}$ \\
\hline
\end{tabular}

$\mathrm{a}, \mathrm{b} \& \mathrm{c}$ : There is no significant difference $(\mathrm{P}>0.05)$ between any two means, within the same column have the same superscript letter.

In general, it could be showed that pan bread produced by partially replacement of their wheat flour with PPP and PSP at level 6, 9, 13.5 and $18 \%$ characterized with a good and satisfactory $(74.95 \pm 2.19-80.05 \pm 1.52)$ sensory properties and acceptability when compared with control sample.

\subsection{Staling of pan bread produced by wheat flour} (72\% ext) and pomegranate peels and seeds.

Staling of pan bread fortified pomegranate peel and seed powder are presented in Table (8). Alkaline water retention capacity (AWRC) of the pan bread loaves could be considered as an indication for staling and freshness. Therefore, it was estimated for each pomegranate peel and seed addition level at zero time and after storage periods (24, 48 and $72 \mathrm{hrs}$.). The presented data showed that,AWRC was increased with increasing pomegranate peel and seed levels and decreased with increasing the storage time in all the pan bread treatments.

The results indicated that non significant difference between control sample and all treatments and the maximum staling value was $392.33 \pm 32.92$ recorded by $\mathrm{T} 4$ followed by $\mathrm{T} 3$ which recorded 374.67 \pm 86.86 , while the minimum staling value was $230.67 \pm 31.18$ recorded by the control sample followed by $\mathrm{T} 1$ which recorded $312.33 \pm 54.49$. The increase of staling value due to the high fiber content in PPP and PSP comparing the wheat flour because the fiber content helps to hold the water. Such results could be illustrated by the findings of Mehder (2013) and Elgindy and Elsarha (2015).

\subsection{Physical properties of producedpan breads:}

Physical attributes (loaf volume, loaf weight, specific volume and height) of pan bread treatments are given in Table (9). The results showed that PPP and seed fortified loaves were lower in loaf volume and higher in loaf weight compared with control sample, while the loaf volume of $18 \%$ PPP and PSP fortified bread was341.67 $\pm 17.64\left(\mathrm{~cm}^{3}\right)$ that control sample was $435.00 \pm 15.28\left(\mathrm{~cm}^{3}\right)$ with $21.4 \%$ reduction. while, the loaf weight of PPP and PSP fortified bread was increased by increasing the substitution of PPP and PSP to reach $152.44 \pm 2.08 \mathrm{~g}$ by $\mathrm{T} 4$ compared to control sample $145.74 \pm 1.88 \mathrm{~g}$ by $4.39 \%$ raising. Bread specific volume decreased significantly from $2.98 \pm 0.09\left(\mathrm{~cm}^{3} / \mathrm{g}\right)$ to $2.24 \pm 0.10$ 
$\left(\mathrm{cm}^{3} / \mathrm{g}\right)$ for control sample and $\mathrm{T} 4$, respectively with increasing PPP and PSP level. The results form Table (8) indicated that there is a significant difference in height loaf between the control sample and all treatments.

Table 8. Staling of produced pan bread (mean \pm SE).

\begin{tabular}{|c|c|c|c|c|c|c|c|c|c|c|}
\hline \multirow{3}{*}{$\begin{array}{c}\text { Treatmen } \\
t\end{array}$} & \multicolumn{8}{|c|}{ Storage period $(\mathrm{hr})$} & \multirow{2}{*}{\multicolumn{2}{|c|}{ Mean of storage }} \\
\hline & \multicolumn{2}{|c|}{$\mathbf{0}$} & \multicolumn{2}{|c|}{24} & \multicolumn{2}{|c|}{48} & \multicolumn{2}{|c|}{72} & & \\
\hline & Value & $\begin{array}{c}\text { Decreas } \\
\text { e }(\%)\end{array}$ & Value & $\begin{array}{c}\text { Decreas } \\
\text { e }(\%)\end{array}$ & Value & $\begin{array}{c}\text { Decreas } \\
\text { e }(\%)\end{array}$ & Value & $\begin{array}{c}\text { Decreas } \\
\text { e }(\%)\end{array}$ & Value & $\begin{array}{c}\text { Decreas } \\
\text { e }(\%)\end{array}$ \\
\hline Control & $\begin{array}{c}230.67 \\
\pm 31.18^{\text {cA }}\end{array}$ & - & $\begin{array}{c}192.33 \\
\pm 3.38^{\mathrm{bAB}}\end{array}$ & 16.62 & $\begin{array}{c}151.67 \\
\pm 22.10^{\mathrm{cB}} \\
\mathrm{C}\end{array}$ & 34.25 & $\begin{array}{c}125.33 \\
\pm 31.76^{\mathrm{cC}}\end{array}$ & 45.67 & $\begin{array}{c}175.00 \\
\pm 16.08^{c}\end{array}$ & 24.13 \\
\hline T1 & $\begin{array}{c}312.33 \\
\pm 54.49^{\mathrm{bA}}\end{array}$ & - & $\begin{array}{c}272.00 \\
\pm 38.22^{\mathrm{aA}} \\
\quad \text { B }\end{array}$ & 12.91 & $\begin{array}{c}225.33 \\
\pm 77.80^{\mathrm{bB}} \\
\mathrm{C}\end{array}$ & 27.86 & $\begin{array}{c}213.67 \\
\pm 89.45^{\text {bC }}\end{array}$ & 31.59 & $\begin{array}{c}255.83 \\
\pm 31.31^{b}\end{array}$ & 18.09 \\
\hline $\mathbf{T} 2$ & $\begin{array}{c}355.33 \\
\pm \underset{A}{46.77^{\text {ab }}}\end{array}$ & - & $\begin{array}{c}293.00 \\
\pm 12.66^{\mathrm{aA}} \\
{ }_{\text {B }}\end{array}$ & $\mathbf{1 7 . 5 4}$ & $\begin{array}{c}257.00 \\
\pm 16.09^{\mathrm{abB}}\end{array}$ & 27.67 & $\begin{array}{c}246.00 \\
\pm 52.12^{\text {ab }} \\
\text { B }\end{array}$ & 30.77 & $\begin{array}{c}287.83 \\
\pm \underset{b}{20.19^{a}}\end{array}$ & 19.00 \\
\hline T3 & $\begin{array}{c}374.67 \\
\pm 86.86^{\text {ab }} \\
A\end{array}$ & - & $\begin{array}{c}301.00 \\
\pm 22.61^{\mathrm{aB}}\end{array}$ & 19.66 & $\begin{array}{c}264.00 \\
\pm 13.61^{\mathrm{abB}}\end{array}$ & 29.54 & $\begin{array}{c}255.00 \\
\pm 17.32^{\mathrm{ab}} \\
\quad \text { B }\end{array}$ & 31.94 & $\begin{array}{c}298.67 \\
\pm \underset{b}{24.30^{a}}\end{array}$ & 20.28 \\
\hline T4 & $\begin{array}{c}392.33 \\
\pm 32.92^{\mathrm{aA}}\end{array}$ & - & $\begin{array}{c}326.67 \\
\pm 53.01^{\mathrm{aB}}\end{array}$ & 16.74 & $\begin{array}{c}297.00 \\
\pm 15.37^{\mathrm{aB}}\end{array}$ & 24.30 & $\begin{array}{c}285.33 \\
\pm 33.02^{\mathrm{aB}}\end{array}$ & 27.27 & $\begin{array}{c}325.33 \\
\pm 19.85^{\mathrm{a}}\end{array}$ & 17.08 \\
\hline $\begin{array}{l}\text { Mean of } \\
\text { treatment }\end{array}$ & $\begin{array}{r}333.07 \\
\pm 25.68^{\mathrm{A}}\end{array}$ & - & $\begin{array}{c}277.00 \\
\pm 17.07^{\mathrm{AB}}\end{array}$ & 16.83 & $\begin{array}{c}239.00 \\
\pm 19.48^{\mathrm{B}}\end{array}$ & 28.24 & $\begin{array}{c}225.07 \\
\pm 24.28^{B}\end{array}$ & 32.43 & & \\
\hline
\end{tabular}

a, b \& c: There is no significant difference (P>0.05) between any two means, within the same column have the same superscript letter.

A, B \& C: There is no significant difference $(\mathrm{P}>0.05)$ between any two means for the same attribute, within the same row have the same superscript letter.

Table 9. Specific volume and height of pan bread (mean \pm SE).

\begin{tabular}{|c|c|c|c|c|}
\hline \multirow[b]{2}{*}{ Treatment } & \multicolumn{4}{|c|}{ Attributes } \\
\hline & $\begin{array}{l}\text { Volume } \\
\left(\mathrm{cm}^{3}\right)\end{array}$ & $\begin{array}{l}\text { Weight } \\
\text { (g) }\end{array}$ & $\begin{array}{l}\text { Specific volume } \\
\left(\mathrm{cm}^{3} / \mathrm{g}\right)\end{array}$ & $\begin{array}{l}\text { Height } \\
(\mathbf{c m})\end{array}$ \\
\hline Control & $435.00 \pm 15.28^{a}$ & $145.74 \pm 1.88^{\mathrm{a}}$ & $2.98 \pm 0.09^{a}$ & $6.62 \pm 0.04^{a}$ \\
\hline T1 & $423.33 \pm 7.26^{a b}$ & $147.99 \pm 3.85^{\mathrm{a}}$ & $2.86 \pm 0.04^{a}$ & $5.81 \pm 0.01^{b}$ \\
\hline $\mathbf{T} 2$ & $376.00 \pm 24.58^{b c}$ & $148.90 \pm 3.85^{\mathrm{a}}$ & $2.52 \pm 0.15^{\mathrm{b}}$ & $5.73 \pm 0.01^{c}$ \\
\hline T3 & $351.67 \pm 12.02^{\mathrm{c}}$ & $149.61 \pm 0.55^{\mathrm{a}}$ & $2.35 \pm 0.07^{b}$ & $5.54 \pm 0.03^{d}$ \\
\hline T4 & $341.67 \pm 17.64^{c}$ & $152.44 \pm 2.08^{\mathrm{a}}$ & $2.24 \pm 0.10^{b}$ & $5.34 \pm 0.02^{\mathrm{e}}$ \\
\hline
\end{tabular}

$\mathrm{a}, \mathrm{b} \& \mathrm{c}$ : There is no significant difference $(\mathrm{P}>0.05)$ between any two means, within the same column have the same superscript letter.

The maximum height value were $6.62 \pm 0.04$ $(\mathrm{cm})$ obtained by control, while the minimum height value were $5.34 \pm 0.02(\mathrm{~cm})$ obtained by $\mathrm{T} 4$.

\section{Conclusion}

The results recommended that pomegranate peel powder (PPP) and pomegranate seed powder (PSP) at levels $(6,9,13.5$ and 18\%) fortified pan bread increased fiber, ash, protien, fat and antioxidant activety and could provide health benefites to pan bread product. Also, addition of PPP and PSP increased staling and water absorption in all pan bread treatments. Addition of PPP and PSP at T2 (9\%) instead of wheat flour increased dough stability time. In this study we recommended addtion of PSP as a source of oil in pan bread instead of corn oil.

\section{Reference}

A.A.C.C. (2000).American Association for Cereal chemistry. $10^{\text {th }}$ Edition. AACC international, St. paul. MN. A.

A.A.C.C. (2010). American Association for Cereal Chemistry. $11^{\text {th }}$ Edition. AACC international, St. paul. MN. A.
A.O.A.C. (2012).Official Methods of Analysis Association of Official Analytical Chemists International, $19^{\text {th }}$ ed., Maryland, USA.

Abd El-Moniem, G.M. and Yaseen, A.A. (1993). High dietary fibre cookies from several sources of bran or husk. Egypt J. Food Sci., 21(2): 157-170.

Bonet, A.; Blaszczak, W. and Rosell, C.M. (2006). Formation of homopolymers and heteropolymers between wheat flour and several protein sources by trans glutaminase-catalyzed cross linking. Cereal Chemistry. 83(6): 655- 662.

Chen, H.; Rubenthaler, G.L. and Schamus, E.C. (1988).Effect of apple fiber and cellulose on the physical properties of wheat flour. J. Food Sci., 53(1): 304-306.

Dadashi, S.; Mousazadeh, M.; Emam-Djomeh, Z. and Mousavi, S.M. (2013). Pomegranate (Punica granatum L.) seed: A comparative study on biochemical composition and oil physicochemical characteristics. International J. of Advanced Biological and Biomedical Research, 1(4): 351363.

Elgindy, A.A.E. and Elsarha, E.S. (2015). Biochemical and technological studies on the effect of pomegranate peel in addition to pan bread 
and its effect on the pollution of cadmium chloride in mice. Advances in Environmental Biology, 9(27): 33-43.

Giusti, M.M. and Wrolstad, R.E. (2001).Characterization and measurement of anthocyaninsby UV-Visible spectroscopy in Current Protocols inFood Analytical Chemistry edited by Wrolstad, R. E.and Schwartz S.J. John Wiley and Sons, New York, USA. pp: 1-13.

Hassan, N.A.; El-Halwagi, A.A. and Sayed, H. (2012). Phytochemicals, antioxidant and chemical properties of 32 pomegranate accessions growing in Egypt. World Applied Sci. J., 16(8): 1065-1073.

Hefnawy, T.M.H.; El-Shourbagy, G.A. and Ramadan, M.F. (2012).Impact of adding chickpea (Cicer arietinum L.) flour to wheat flour on the rheological properties of toast bread. International Food Research J., 19(2): 521-525.

Holma, R.; Hongisto, S.M.; Saxelin, M. and Korpela, R. (2010). Constipation is relieved more by rye bread than wheat bread or laxatives without increased adverse gastrointestinal. Journal of Nutrition, 140(3): 534-541.

Jensen, S.; Oestdal, H.; Clausen, M.R.; Andersen, M.L. and Skibsted, L.H. (2011). Oxidative stability of whole wheat bread during storage. LWT-Food Science and Technology, 44(3): 637642.

Khorshid, A.M.; Assem, N.; Abd, E. and Fahim, J. (2011). Utilization of flaxseeds in improving bread quality. Egypt J. Agric. Res., 89: 241-250.

Kitterman, J. and Rubenthaler, G. (1971). Application of the Brookfield viscometer for measuring the apparent viscosity of acidulated flour-water suspensions. Cereal science today.

Li, Y.; Guo, C.; Yang, J.; Wei, J.; Xu, J. and Cheng, S. (2006). Evaluation of antioxidant properties of pomegranate peel extract in comparison with pomegranate pulp extract. Food Chemistry, 96(2): 254-260.

Lu, J., Zhao, H., Chen, J., Fan, W., Dong, J., Kong, W., Sun, J., Cao, Y. and Cai, G. (2007) Evolution of Phenolic Compounds and Antioxidant Activity durnig Malting. Journal of Agricultural and Food Chemistry, 55, 10994-11001.https:// doi.org/ 10.1021/jf0722710

Makkar, H. P. S., Siddhuraju, P., and Becker, K. (2007).Plant secondary metabolites (pp. 74-75). Totowa: NJ, USA Humana Press.

Mehder, A.O.A. (2013). Pomegranate peels effectiveness in improving the nutritional, physical and sensory characteristics of pan bread. Current Science Internationa, 12(2): 8-14.

Mello, V.D. and Laaksonen, D.E. (2009). Fibras na dieta: tendéncias atuais e beneficios á saúde na síndrome metabólica e no diabetes melito tipo 2 . Arq. Bras endocrinol. Metab., 53(5): 509-518.

Metoui, M.; Essid, A.; Bouzoumita, A. and Ferchichi, A. (2019). Chemical Composition, Antioxidant and Antibacterial Activity of Tunisian
Date Palm Seed. Pol. J. Environ. Stud. Vol. 28(1): 267-274.

Mohagheghi, M.;Rezaei, K.;Labbafi, M. and Seyyed, M. (2011). Pomegranate seed oil as a functional ingredient in beverages. European $\mathrm{J}$. Lipid Sci. and Tech., 113(6): 730-736.

Mozaffarian, R.S.; Lee, R.M., Kennedy, M.A.; Ludwig, D.S.; Mozaffarian, D. and Gortmaker, S.L. (2013). Identifying whole grain foods: a comparison of different approaches for selecting more healthful whole grain products. Public Health Nutrition, 16(12): 2255-2264.

Niu, M.; Hou, G.; Lee, B. and Chen, Z. (2014). Effects of fine grinding of millfeeds on the quality attributes of reconstituted whole-wheat flour and its raw noodle products. LWT-Food Science and Technology, 57(1): 58-64.

Okarter, N. and Liu, R.H. (2010). Health benefits of whole grain phytochemicals. Critical Reviews in Food Science and Nutrition, 50(3): 193-208

Ozturk, S.; Kahraman, K.; Tiftik, B. and Koksel, H. (2008). Predicting the cookie quality of flours by using Mixolab. European Food Research and Technology, 227(5): 1549 -1554.

Parcerisa, J.; Rafecas, M.; Castellote, A.; Codony, R.; Farran, A.; Garcia, J.; Gonzalez, C.; Lopez, A.; Romero, A. and Boatella (1995). Influence of variety and geographical origin on the lipid fraction of hazelnuts (Corylus avellana L.) from Spain: (III) oil stability, tocopherol content and some mineral contents $(\mathrm{Mn}, \mathrm{Fe}, \mathrm{Cu})$. Food Chemistry, 53(1): 71-74.

Rowayshed, G.; Salama, A.; Abul-Fadl, M.; AkilaHamza, S. and Emad, M. (2013). Nutritional and chemical evaluation for pomegranate (Punica granatum L.) fruit peel and seeds powders by products. Middle East J. Applied Sciences, 3(4): 169-179.

Sayed-Ahmed, E.F. (2014). Evaluation of pomegranate peel fortified pan bread on body weight loss. International J. Nutrtion Food Science, 3(5): 411-420.

Singleton, R.J.A.J. (1965). Colorimetry of total phenolics with phosphomolybdic-phosphotungstic acid reagents. American J. Enology and Viticulture. 16: 144-158.

Slavin, J.L. (2008). Position of the American Dietetic Association: health implications of dietary fiber. Journal of the American Dietetic Association, 108(10): 1716-1731.

Sluimer, P. (2005). Principles of Bread Making: Functionality of Raw Materials and Process Steps. American Association of Cereal Chemists. Paul, MN, USA.

Steel, R.; Torrie, J. and Dickey, D. (1997). Principles and Procedures of Statistics: A Biometrical Approach. $3^{\text {rd }}$ Ed, McGraw-Hill, New York, USA.

Tacouri, D.D.; Ramful-Baboolall, D. and Puchooa, D. (2013). In vitro bioactivity and phytochemical 
screening of selected spices used in Mauritian foods. Asian Pacific J. Tropical Disease, 3(4): 253261.
Yamazaki, W.J.C.C. (1953). An alkaline water retention capacity test for the evaluation of cookie baking potentialities of soft winter wheat flours.Cereal Chemistry, 30 (3): 242-246.

$$
\begin{aligned}
& \text { تأثير إضافة مسحوق قشور ويذور الرمان على خصائص الجودة لخبز القوالب }
\end{aligned}
$$

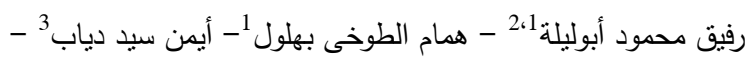

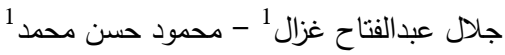

$$
\begin{aligned}
& 1 \text { قسم الصناعات الغذائية -كلية الزراعة - جامعة بنها- القليوبية- مصر . } \\
& \text { 2شركة هيرو للصناعات الغذائية- ترسا - القليوبية- مصر }
\end{aligned}
$$

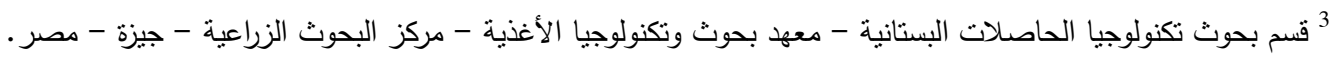

الهدف من هذا البحث هو دراسة تأثير إضافة قثور وبذور الرمان المجفة على الخصائص الكيميائية، الفيزيائية، الحسية و الريولوجية

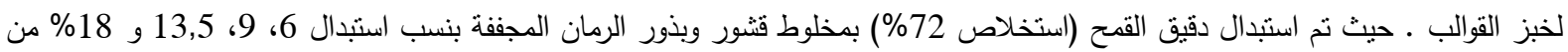
دقيق القمح. أوضحت نتائج التركيب الكيماوى زيادة فى محتوى الخبز من البروتين، الدهن، الألياف والعناصر المعدنية مقارنة بالكونترول فى حين

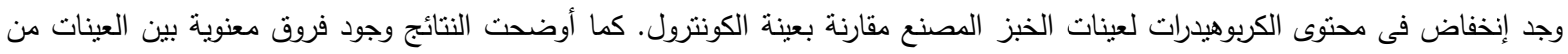
حيث محتوى المواد الفينولية والفلافونيدية وكذللك النشاط المضاد للأكسدة. كما أوضحت النتائج أن عينة المقارنة سجلت أقل قيم بلتينة بالنسبة للمواد

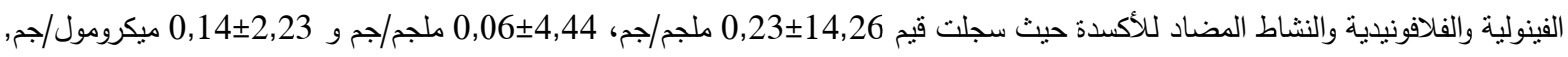
على التوالى بينما سجلت العينة T4 (6\% قثر مجف +12\% بذور مجففة) أعلى محتوى من المواد الفينولية والفلافونيدية والنشاط المضاد للأكسدة

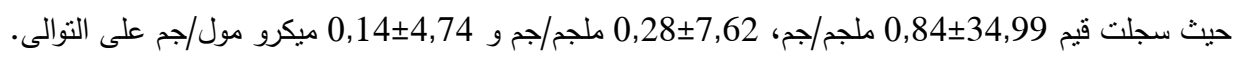
أوضحت نتائج التحكيم الحسي أن عينة المقارنة (الكنترول) سجلت أعلى قيم بالنسبة للمظهر العام، لون القصرة، ولون اللبابة، ونوزيع مولهي

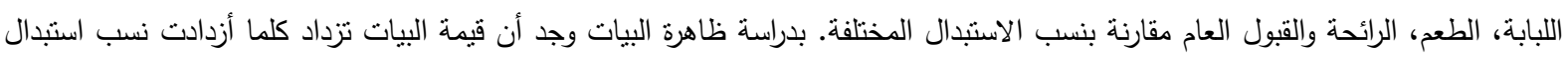

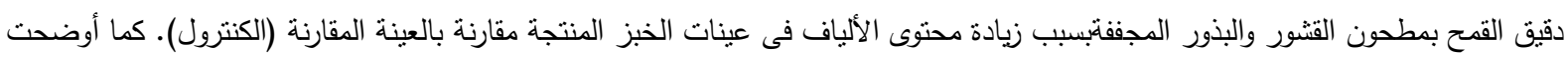

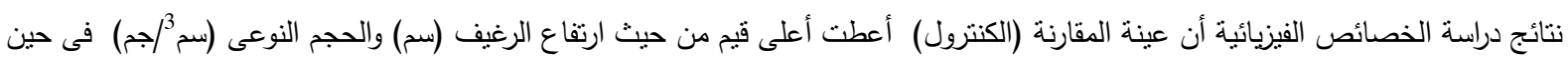
أعطت اقل قيم من حيث الوزن (جم) مقارنة بنسب الاستبدال. أظهرت نتائج دراسة الخصائص الريولوجية زيادة فى قدرة الدقيق على امتصاص الماء الماء وزمن تطور العجين كلما زادت نسب الاستبدال فى حين أنخفض زمن ثنات العجين وانخفضت قوة العجين كلما زادت نسب الاستبدال بمطحون

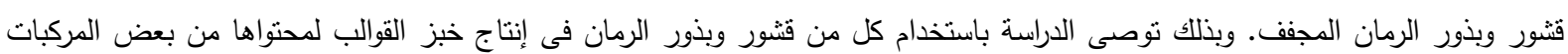
الحيوية التى قد يحتا 